\section{Managing Bitter Pit in 'Honeycrisp' Apples Grown in the Mid-Atlantic United States with Foliar-applied Calcium Chloride and Some Alternatives}

\author{
Alan R. Biggs ${ }^{1,3,5}$ and Gregory M. Peck ${ }^{2,4}$
}

\begin{abstract}
AdDitional InDEX wORDs. Malus $\times$ domestica, bitter rot, Colletotrichum
Summary. Three separate experiments were conducted to test standard calcium chloride salt $\left(\mathrm{CaCl}_{2}\right)$ rates and several new formulations of calcium $(\mathrm{Ca})$ for amelioration of bitter pit, a Ca-related physiological disorder that affects fruit of many apple (Malus $\times$ domestica) cultivars, including the popular cultivar Honeycrisp. Even small amounts of bitter pit damage make apples unmarketable. We evaluated various formulations of $\mathrm{Ca}$ to compare their effectiveness in controlling bitter pit, including proprietary Ca products ( $\mathrm{InCa}^{\mathrm{TM}}$, Sysstem-Cal ${ }^{\mathrm{TM}}$, Vigor-Cal ${ }^{\mathrm{TM}}, \mathrm{XD} 10$, and XD505) with and without antitranspirant. Calcium chloride is the most common Ca product used to reduce bitter pit incidence, but it has negative impacts, such as phytotoxicity and corrosiveness. Of the products that were tested in 2011, $\mathrm{XD} 10$ at the high rate and XD505 are candidates for future study. In 2012, both the $\mathrm{CaCl}_{2}$ and XD10 treatments had lower bitter pit severity than the nontreated control, but only the $\mathrm{CaCl}_{2}$ treatments had a lower total percentage of fruit with bitter pit compared with the control. The antitranspirant reduced bitter pit incidence in one of three treatments. Full season Ca treatments and higher rates (up to $23.5 \mathrm{lb}$ /acre per season of elemental $\mathrm{Ca}$ ) are needed to significantly reduce bitter pit incidence in 'Honeycrisp' apples in the mid-Atlantic United States.
\end{abstract}

A lthough 'Honeycrisp' apples are very popular with consumers, they are prone to a number of production difficulties, which in turn make them challenging to grow and store. One of these challenges is bitter pit, a physiological disorder that has long been associated with low fruit Ca content (Schupp et al., 200la, $200 \mathrm{lb}$ ), though greater Ca flesh mineral content is not always associated with lower bitter pit incidence (Watkins et al., 2004). Calcium is not very mobile

Appreciation is extended to David Carbaugh, Abby Kowalski, David Leach, and Tim Winfield for technical assistance. Funding for this work was provided in part by the Virginia and West Virginia Agricultural Experiment Stations and the Hatch Program of the National Institute of Food and Agriculture, U.S. Department of Agriculture.

Mention of a trademark, proprietary product, or vendor does not constitute a guarantee or warranty of the product by Virginia Tech or West Virginia University and does not imply its approval to the exclusion of other products or vendors that also may be suitable.

${ }^{1}$ Division of Plant and Soil Science, West Virginia University, Kearneysville Tree Fruit Research and Education Center, P.O. Box 609, Kearneysville, WV 25430

${ }^{2}$ Department of Horticulture, Virginia Polytechnic Institute and State University, Alson H. Smith, Jr. Agricultural Research and Extension Center, 595 Laurel Grove Road, Winchester, VA 22602

${ }^{3}$ Professor of Plant Pathology.

${ }^{4}$ Assistant Professor of Horticulture.

${ }^{5}$ Corresponding author. E-mail: alan.biggs@mail.wvu.edu. within trees, so apple growers must apply foliar $\mathrm{Ca}$ on multiple occasions through the growing season. Bitter pit symptomatically appears as dark sunken lesions on the peel and brown, oxidized flesh that may extend up to $\mathrm{l} \mathrm{cm}$ below the fruit surface. The disorder may be visible at harvest, but more commonly, it develops after several weeks in storage. Bitter pit is reportedly exacerbated under hot, dry growing conditions, in young orchards (less than 5 years old), when fruit size is large, when boron is deficient, and/or when soil $\mathrm{pH}$ is low (Fallahi et al., 2010; Rosenberger et al., 2001; Telias et al., 2006; Watkins et al., 2004).
Apple growers mitigate bitter pit by applying Ca to apple trees, most often in the form of $\mathrm{CaCl}_{2}$ (Neilsen et al., 2005; van Goor, 1971). However, $\mathrm{CaCl}_{2}$ is difficult to mix into solution and can cause salt burn on the leaves after repeated applications (especially in hot, dry seasons). In addition, $\mathrm{CaCl}_{2}$ is corrosive to tractors and sprayers. Calcium products that do not have these negative side effects have long been sought, but it has been difficult to match the efficacy of $\mathrm{CaCl}_{2}$.

Several new Ca products have been brought to the market recently, and several more are being tested for potential commercialization. For example, Miller Chemical and Fertilizer Corp. of Hanover, PA (Miller Chemical) has a product that contains the proprietary $\mathrm{CaT}$ (calcium technology), a patented "calcium absorption aid" produced by Plant Impact PLC (Preston, UK) that is reported to chemically bond $\mathrm{Ca}$ to create molecules that, in the absence of auxin, can operate the auxin-calcium countertransport pump. By overriding this mechanism, it should theoretically allow $\mathrm{Ca}$ to be taken in by plant organs that would otherwise be poor Ca sinks; i.e., apple flesh tissue. Fertilizer products with $\mathrm{CaT}$, such as $\mathrm{InCa}^{\mathrm{TM}}$ (Miller Chemical) and similar experimental products reported in this article, are advertised to improve plant growth and fruit quality by reducing the negative effects of abiotic stresses, but there are few published reports about these products in the scientific literature. Sweet cherry (Prunus avium) trees treated with $\mathrm{InCa}^{\mathrm{TM}}$ increased $\mathrm{Ca}$ concentration and dry matter in fruits and leaves relative to an untreated control; however, this experiment did not compare

\begin{tabular}{llll}
\hline $\begin{array}{l}\text { units } \\
\begin{array}{l}\text { To convert U.S. to SI, } \\
\text { multiply by }\end{array}\end{array}$ & U.S. unit & SI unit & $\begin{array}{l}\text { To convert SI to U.S., } \\
\text { multiply by }\end{array}$ \\
\hline 0.3048 & $\mathrm{ft}$ & $\mathrm{m}$ & 3.2808 \\
9.3540 & $\mathrm{gal} / \mathrm{acre}$ & $\mathrm{L} \cdot \mathrm{ha}^{-1}$ & 0.1069 \\
2.54 & inch $(\mathrm{es})$ & $\mathrm{cm}$ & 0.3937 \\
25.4 & inch $(\mathrm{es})$ & $\mathrm{mm}$ & 0.0394 \\
0.4536 & $\mathrm{lb}$ & $\mathrm{kg}$ & 2.2046 \\
1.1209 & $\mathrm{lb} / \mathrm{acre}$ & $\mathrm{kg} \cdot \mathrm{ha}^{-1}$ & 0.8922 \\
0.1198 & $\mathrm{lb} / \mathrm{gal}$ & $\mathrm{kg} \cdot \mathrm{L}^{-1}$ & 8.3454 \\
4.4482 & $\mathrm{lbf}$ & $\mathrm{N}$ & 0.2248 \\
28.3495 & $\mathrm{oz}$ & $\mathrm{g}$ & 0.0353 \\
1 & $\mathrm{ppm}$ & $\mathrm{mg} \cdot \mathrm{L}^{-1}$ & 1 \\
0.9464 & $\mathrm{qt}$ & $\mathrm{L}$ & 1.0567 \\
2.3385 & $\mathrm{qt} / \mathrm{acre}$ & $\mathrm{L} \cdot \mathrm{ha}^{-1}$ & 0.4276 \\
$\left({ }^{\circ} \mathrm{F}-32\right) \div 1.8$ & ${ }^{\circ} \mathrm{F}$ & ${ }^{\circ} \mathrm{C}$ & $\left({ }^{\circ} \mathrm{C} \times 1.8\right)+32$ \\
& & & \\
& & &
\end{tabular}

Hortlechnology · June 2015 25(3) 
InCa ${ }^{\top \mathrm{M}}$ against $\mathrm{CaCl}_{2}$ or other $\mathrm{Ca}$ products (Mikiciuk et al., 2015). In addition, there are several Agro-K (Minneapolis, MN) Ca products (i.e., Sysstem-Cal ${ }^{\mathrm{TM}}$ and Vigor-Call ${ }^{\mathrm{TM}}$ ), as well as the antitranspirant Vapor Gard ${ }^{\circledR}$ (Miller Chemical), which is thought to reduce transpiration rates and thus mitigate bitter pit development. Similar to $\mathrm{InCa}^{\mathrm{TM}}$, peer-reviewed reports on Sysstem-Cal' ${ }^{T M}$, Vigor-Cal' ${ }^{T M}$, and antitranspirant are lacking.

The overall goal of our experiments was to develop useful recommendations for reducing bitter pit in mid-Atlantic U.S. 'Honeycrisp' orchards. Our specific objectives were to 1$)$ test the efficacy of several proprietary liquid $\mathrm{Ca}$ formulations, 2) test the hypothesis that an antitranspirant can reduce bitter pit incidence, 3 ) determine $\mathrm{CaCl}_{2}$ application rates for control of bitter pit in 'Honeycrisp' apples, and 4) compare total Ca rates per year among the different product formulations.

\section{Materials and methods}

Experiments 1 and 2 were conducted in a 'Honeycrisp'/'Malling Merton 111' (MM.111) orchard, with trees spaced $10 \times 23 \mathrm{ft}$ that was established in 2007 at Virginia Tech's Alson H. Smith, Jr. Agricultural Research and Extension Center in Winchester, VA. The application rate was based on $100 \mathrm{gal} / \mathrm{acre}$ of water and applications were made with a handgun to the point of drip. Experiment 1 was conducted in 2011 and consisted of six single-tree replications of seven treatments in a randomized complete block design. To reduce the effect of crop load on this experiment, treatments were blocked by flower density. The treatments included $\mathrm{CaCl}_{2}(36 \% \mathrm{Ca}$; Dow Chemical Co., Midland, MI) at a low (2 lb/ application $\mathrm{CaCl}_{2}$ ) and high application rate $\left(5 \mathrm{lb}\right.$ /application $\left.\mathrm{CaCl}_{2}\right) ; \mathrm{InCa}^{\mathrm{TM}}$ [5\% Ca, $4 \%$ nitrogen $(\mathrm{N}), 10.85 \mathrm{lb} / \mathrm{gal}]$ at $1 \mathrm{qt} /$ application; and two experimental Miller Chemical products that are similar to InCa ${ }^{T \mathrm{M}}$, but with different levels of $\mathrm{Ca}$ and nitrogen: $\mathrm{XD} 10$ $(10 \% \mathrm{Ca}, 6 \% \mathrm{~N})$ at $\mathrm{l}$ and $2.65 \mathrm{qt} /$ application and XD505 (5\% Ca, 0\% N) at $1 \mathrm{qt} /$ application. Each treatment was applied nine times, starting at petal fall (30 Apr.) and continuing at $\approx 2$-week intervals (14 May, 27 May, 13 June, 24 June, 10 July, 25 July, 5 Aug., and 20 Aug.).
Experiment 2 was conducted in 2012 on the same block of 'Honeycrisp' trees and consisted of eight single-tree replications of eight treatments in a randomized complete block design. To reduce the effect of crop load on this experiment, treatments were blocked by flower density. The treatments included an untreated control, a full season of $\mathrm{CaCl}_{2}$ (3 lb/application); a late season (mid- to late-summer) of $\mathrm{CaCl}_{2}$ (3 lb/application); a full season of $\mathrm{CaCl}_{2}$ (3 lb/application) mixed with antitranspirant (2 qt/application); XD10 (1.5 qt/application); XDl0 (1.5 qt/application) mixed with antitranspirant (2 qt/application); a combination of Sysstems-Cal ${ }^{\mathrm{TM}}$ [4\% Ca, $0.25 \%$ copper $(\mathrm{Cu}), 10 \mathrm{lb} / \mathrm{gal}](2 \mathrm{qt})$ application) for the first three applications and then Vigor-Cal ${ }^{\mathrm{TM}}(5 \% \mathrm{Ca}$, $10 \mathrm{lb} / \mathrm{gal})(2 \mathrm{qt} /$ application $)$ for the remaining applications, and a combination of Sysstems-Cal'TM (2 qt/application) for the first three applications and then Vigor-Cal ${ }^{\mathrm{TM}}$ (2 qt/application) for the remaining applications mixed with antitranspirant ( 2 qt/application). Application dates were as follows: $\mathrm{CaCl}_{2}$ (full season) and $\mathrm{XDl} 0$ treatments, 20 April (petal fall), 30 Apr., 10 May, 24 May, 7 June, 21 June, 5 July, 19 July, 2 Aug.; $\mathrm{CaCl}_{2}$ (late season) treatments, 21 June, 5 July, 19 July, 2 Aug.; Sysstem-Cal ${ }^{T M}, 20$ Apr., 30 Apr., and 10 May, followed by Vigor-Cal ${ }^{\mathrm{TM}}$ 24 May, 7 June, 21 June, 5 July, 19 July, and 2 Aug. Antitranspirant was added on 7 June, 5 July, and 2 Aug. Calcium chloride treatment rates were selected to match standard grower practices in Virginia, whereas the manufacturers recommended the liquid formulation rates (Pfeiffer et al., 2014). The lateseason applications of $\mathrm{CaCl}_{2}$ were included to see if full season applications are necessary to reduce bitter pit in 'Honeycrisp' apples.

For experiments 1 and 2, bitter pit was evaluated at harvest, after $30 \mathrm{~d}$ (2011) and/or $45 \mathrm{~d}$ (2011 and 2012) in refrigerated $\left(34^{\circ} \mathrm{F}\right)$ storage. A 10fruit sample from each treatment per replication (60 fruit in 2011, 80 fruit in 2012) was used for each evaluation. In 2011 , the same fruit was used for the 30- and 45-d bitter pit evaluations. Bitter pit incidence was determined as percent of fruit with symptoms; severity was rated on a zero to three scale as follows: $0=$ no bitter pit observed; $1=$ less than $15 \%$ of the apple's surface was affected; $2=15 \%$ to $35 \%$ of the fruit surface affected; and $3=$ greater than $35 \%$ of the fruit surface observed with bitter pit. Additional standard fruit maturity and quality measurements were conducted at harvest and after $45 \mathrm{~d}$ in storage, as described in ThompsonWitrick et al. (2014). Briefly, apples were weighed and visually assessed for percent red blush (0\% to 100\%). Flesh firmness was measured on the same samples, after removing part of the peel at two locations along the equator of each apple, with a Fruit Texture Analyzer penetrometer (Güss Manufacturing, Strand, South Africa) fitted with a cylindrical 11.1-mm-diameter Effegi tip. Starch index was determined by staining the stem-side of an equatorial cross-section of the apples with iodine solution $(0.22 \% \mathrm{w} / \mathrm{v}$ iodine, $0.88 \% \mathrm{w} / \mathrm{v}$ potassium iodine) and visual rating, where $1=100 \%$ staining and $8=0 \%$ staining. Soluble solids concentration was measured using a digital refractometer (PAL-1; Atago U.S.A., Bellevue, WA). Internal ethylene was measured on a $1 \mathrm{~mL}$ sample removed from the core cavity of the apple using a gas chromatograph (7890; Agilent Technologies, Wilmington, DE) equipped with a flame ion detector.

Experiment 3 was conducted in 2010 and 2012 at West Virginia University's Tree Fruit Research and Education Center in Kearneysville, WV. 'Honeycrisp' apple trees, established in 2001 on M.7a rootstock spaced in the orchard at $16 \times 20 \mathrm{ft}$, were treated in both years with 35.0, 50.0 , and $65.0 \mathrm{lb} /$ acre per season using Briner's calcium chloride (95\% anhydrous $\mathrm{CaCl}_{2}$ ) in a completely randomized design. Each plot received $5.0 \mathrm{lb} /$ acre every other week in cover spray applications with insecticides and fungicides beginning at first cover and applied with an airblast sprayer calibrated to deliver 100 gal/acre. The medium- and high-rate plots received additional $\mathrm{CaCl}_{2}$ only in the intervening week of 2.5 and 5.0 $\mathrm{lb} / \mathrm{acre}$, respectively; bringing the total application amounts in a 2 -week period to $5.0,7.5$, and $10.0 \mathrm{lb} /$ acre with the latter two in split applications. The second week of the seventh cover application was not made because of weather conditions that led to early harvest in both years. Application dates in 2010 were 10 May, 25 May, 11 June, 23 June, 7 July, 23 July, and 
11 Aug., with intervening week applications made on 17 May, 4 June, 18 June, 30 June, 14 July, and 4 Aug. Application dates in 2012 were 10 May, 24 May, 10 June, 22 June, 6 July, 22 July, and 10 Aug., with intervening week applications made on 16 May, 3 June, 17 June, 29 June, 13 July, and 3 Aug.

Trees were harvested on 23 Aug. 2010 and 20 Aug. 2012, and evaluated for bitter pit incidence immediately. An apple was considered to have bitter bit if it exhibited any evidence of the disorder. Each replication from each treatment consisted of 100 fruit randomly selected from the periphery of the tree. Ten additional fruit were collected from each replicate to determine percent soluble solids and fruit firmness at harvest as previously described (Biggs et al., 1993; Biggs and Miller, 2001). In 2012, following the first assessment, they were placed into refrigerated storage at $\approx 34^{\circ} \mathrm{F}$ for $90 \mathrm{~d}$ and then assessed again for bitter pit and rot incidence. An apple was considered to have rot if it exhibited any evidence of fungal colonization that penetrated into the flesh.

Data from all three experiments were subjected to analysis of variance and means separation procedures using SAS (version 9.1; SAS Institute Cary, NC). Trees used in these experiments were neither irrigated nor fertilized during the course of the study and all were managed for weeds, insects, and diseases according to current recommendations (Pfeiffer et al., 2014).

\section{Results and discussion}

Experiment 1: Growing conditions in 2011 transitioned from a cool, wet spring to a summer with above average temperatures and below average precipitation. From April to August, there were $0,1,5,15$, and $3 \mathrm{~d}$ per month with temperatures above $90^{\circ} \mathrm{F}$, and 6.9, 4.6, 2.9, 1.1, and 2.3 inches of rain. Although hot, dry conditions are known to exacerbate bitter pit development in apples, the at-harvest bitter pit rating was low (average of 0.1 on the four-point scale) in all treatments (Table 1). At harvest, the greatest bitter pit rating was 0.3 for the $2-\mathrm{lb} /$ acre $\mathrm{CaCl}_{2}$ treatment. When the results were calculated based on the presence or absence of any bitter pit, the $2 \mathrm{lb} /$ acre $\mathrm{CaCl}_{2}$ treatment had greater bitter pit than the $5 \mathrm{lb} /$ acre $\mathrm{CaCl}_{2}$ and the $\mathrm{InCa}^{\mathrm{TM}}$ treatments. There were no other statistical differences among the treatments.

After $30 \mathrm{~d}$ in refrigerated storage, the control and the $\mathrm{InCa}^{\mathrm{TM}}$ treatments had greater bitter pit incidence and severity levels than the other treatments; other treatments were not statistically different (Table 1 ). This trend continued to the evaluation at $45 \mathrm{~d}$ in refrigerated storage evaluation, which was conducted on the same fruit, with all treatments increasing in bitter pit incidence and severity. At harvest, some differences were observed among the treatments for fruit diameter and fruit weight, but the magnitude of the difference was small (Table 2). At harvest, the

Table 1. Bitter pit incidence of 'Honeycrisp'/'Malling Merton 111' (MM111) apples treated with varying amounts of calcium $(\mathrm{Ca})$ chloride $\left(\mathrm{CaCl}_{2}\right)$ and other calcium products in Winchester, VA in 2011 when measured in 2011 at harvest (26 Aug.), and after $30 \mathrm{~d}(23$ Sept.) and $45 \mathrm{~d}$ in refrigerated storage (10 Oct.).

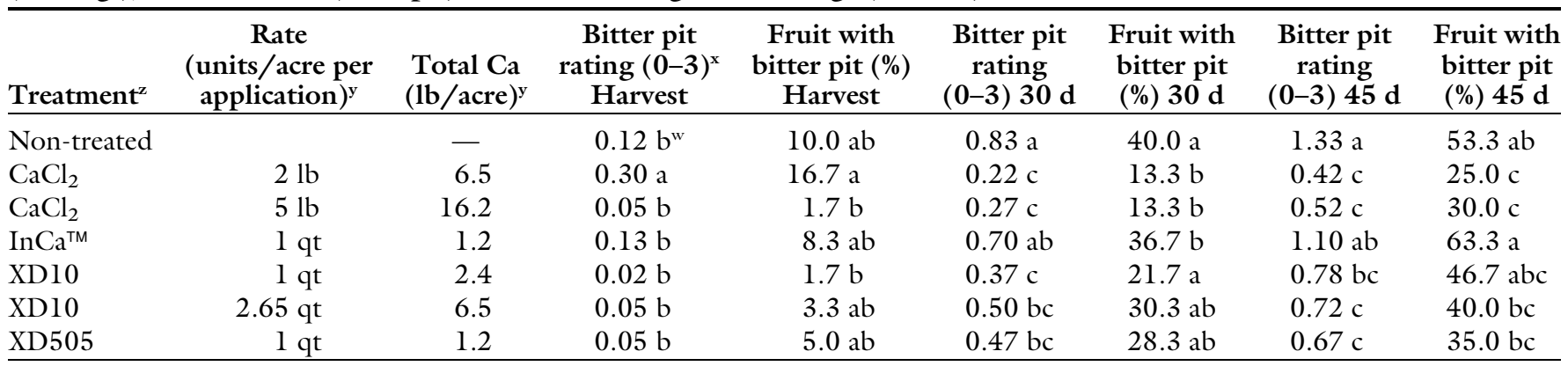

${ }^{\mathrm{z}}$ Each treatment was replicated six times and each value is the mean from 10 fruit/replication (60 fruit). Sprays were applied on 30 Apr., 14 May, 27 May, 13 June, 24 June, 10 July, 25 July, 5 Aug., and 20 Aug. InCa ${ }^{\mathrm{TM}}$, XD10, and XD505 are proprietary calcium products from Miller Chemical and Fertilizer Corp., Hanover, PA.

y $1 \mathrm{lb} /$ acre $=1.1209 \mathrm{~kg} \cdot \mathrm{ha}^{-1}, \mathrm{l} \mathrm{qt} / \mathrm{acre}=2.3385 \mathrm{~L}^{\circ} \mathrm{ha}^{-1}$.

${ }^{\mathrm{x}} 0=$ no bitter pit; $1=$ light amount of bitter pit, less than $15 \%$ surface area affected; $2=$ moderate amount of bitter pit, between $15 \%$ and $35 \%$ surface area affected; and $3=$ severe (heavy) amount of bitter pit, greater than $35 \%$ surface area affected.

wean separation within column by least significant difference test $(P \leq 0.05)$.

Table 2. Fruit weight, red peel color, fruit flesh firmness, soluble solids, and starch index of 'Honeycrisp'/'Malling Merton $111^{\prime}(M M 111)$ apples treated with varying amounts of calcium $(\mathrm{Ca})$ chloride $\left(\mathrm{CaCl}_{2}\right)$ and other calcium products in Winchester, VA in 2011 when measured at harvest (26 Aug.).

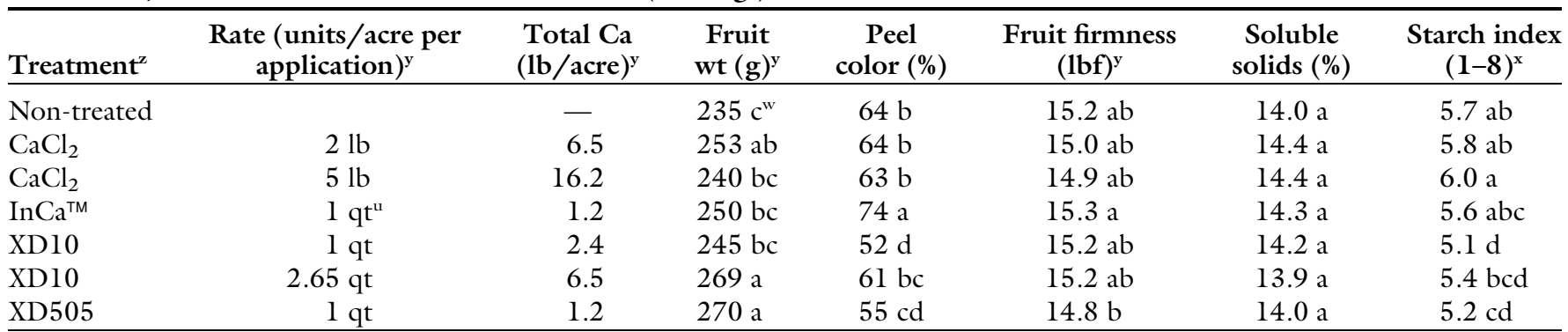

${ }^{2}$ Each treatment was replicated six times and each value is the mean from 10 fruit/replication (60 fruit). Sprays were applied on 30 Apr., 14 May, 27 May, 13 June, 24 June, 10 July, 25 July, 5 Aug., and 20 Aug. 2011. InCa ${ }^{\mathrm{TM}}$, XD10, and XD505 are proprietary calcium products from Miller Chemical and Fertilizer Corp., Hanover, PA.

y l lb/acre $=1.1209 \mathrm{~kg} \cdot \mathrm{ha}^{-1}, 1 \mathrm{qt} / \mathrm{acre}=2.3385 \mathrm{~L} \cdot \mathrm{ha}^{-1}, 1 \mathrm{lbf}=4.4482 \mathrm{~N}, 1 \mathrm{~g}=0.0353 \mathrm{oz}$.

${ }^{x}$ Starch index was determined by staining the stem-side of an equatorial cross-section of the apples with iodine solution $(0.22 \% \mathrm{w} / \mathrm{v}$ iodine, $0.88 \% \mathrm{w} / \mathrm{v}$ potassium iodine) and visual rating, where $1=100 \%$ staining and $8=0 \%$ staining.

"Mean separation within column by the least significant difference test $(P \leq 0.05)$. 
XD10 and XD505 treatments had less red color and starch degradation than the other treatments. Although these differences were small, this is potentially an indicator that these treatments slightly delayed maturity in this experiment. However, there were no differences in fruit firmness or soluble solids concentration. After $45 \mathrm{~d}$ in refrigerated storage, the InCa ${ }^{T M}$ treatment had the greatest red coloration, while the XD10 at $1 \mathrm{qt} /$ acre and XD505 at 1 qt/acre treatments had the least amount (Table 3). The $\mathrm{InCa}^{\mathrm{TM}}$ treatment also had greater firmness than the XD505 at lqt/acre treatment, but other treatments were not statistically different from either or each other. There were small or no difference among the treatments for soluble solids or starch content. Overall, the treatments had few fruit quality differences.

Of the products that were tested in 2011, XD10 at the high rate and XD505 should be targeted for future study. The $\mathrm{CaCl}_{2}$ at $2 \mathrm{lb} /$ acre rate treatment had the highest bitter pit severity at harvest, but was similar to the $\mathrm{CaCl}_{2}$ at $5 \mathrm{lb} /$ acre rate in the stored fruit. The $\mathrm{CaCl}_{2}$ treatments had the least amount of bitter pit at both $30 \mathrm{~d}$ and $45 \mathrm{~d}$ in storage, but these were not statistically different from either of the $\mathrm{XD} 10$ or the $\mathrm{XD} 505$ treatments. InCa ${ }^{\mathrm{TM}}$ did not appear to work as well as the XD10 or the XD505 treatments for controlling bitter pit in 'Honeycrisp'. At most of the measured intervals, bitter pit was similar between the nonsprayed control and $\mathrm{InCa}^{\mathrm{TM}}$. It would be interesting to determine how a higher rate of XD505 compares to $\mathrm{CaCl}_{2}$ at a similar rate of $\mathrm{Ca}$.

Experiment 2: In 2012, several weeks of hot, dry weather conditions in July were favorable for bitter pit development. From April to August, there were $0,0,4,13$, and $0 \mathrm{~d}$ per month with temperatures above $90^{\circ} \mathrm{F}$, and $2.0,2.6,3.4,4.5$, and 4.6 inches of rain. Crop load was similar among

Table 3. Fruit weight, red peel color, fruit flesh firmness, soluble solids, and starch index of 'Honeycrisp' /'Malling Merton 111 ' (MM111) apples treated with varying amounts of calcium $(\mathrm{Ca})$ chloride $\left(\mathrm{CaCl}_{2}\right)$ and other calcium products in Winchester, VA in 2011 when measured after $45 \mathrm{~d}$ (10 Oct.) in refrigerated storage.

\begin{tabular}{|c|c|c|c|c|c|c|c|}
\hline Treatment $^{\mathrm{z}}$ & $\begin{array}{l}\text { Rate (units/acre per } \\
\text { application) }\end{array}$ & $\begin{array}{c}\text { Total Ca } \\
(\mathrm{lb} / \mathrm{acre})^{\mathrm{y}}\end{array}$ & $\begin{array}{c}\text { Fruit } \\
\text { wt }(g)^{y}\end{array}$ & $\begin{array}{c}\text { Peel } \\
\text { color }(\%) \\
\end{array}$ & $\begin{array}{l}\text { Fruit firmness } \\
(\text { (lbf })^{y}\end{array}$ & $\begin{array}{c}\text { Soluble } \\
\text { solids (\%) }\end{array}$ & $\begin{array}{l}\text { Starch index } \\
(1-8)^{x} \\
\end{array}$ \\
\hline Non-treated & & - & $221 b^{w}$ & $61 \mathrm{ab}$ & $15.1 \mathrm{a}$ & $14.5 \mathrm{~b}$ & $7.8 \mathrm{ab}$ \\
\hline $\mathrm{CaCl}_{2}$ & $2 \mathrm{lb}$ & 6.5 & $263 \mathrm{a}$ & $67 \mathrm{a}$ & $15.1 \mathrm{a}$ & $15.0 \mathrm{a}$ & $7.8 \mathrm{ab}$ \\
\hline $\mathrm{CaCl}_{2}$ & $5 \mathrm{lb}$ & 16.2 & $224 \mathrm{~b}$ & $58 \mathrm{bc}$ & $14.9 \mathrm{a}$ & $14.7 \mathrm{ab}$ & $7.8 \mathrm{ab}$ \\
\hline $\mathrm{InCa}^{\mathrm{TM}}$ & $1 \mathrm{qt}^{\mathrm{u}}$ & 1.2 & $252 \mathrm{a}$ & $51 \mathrm{c}$ & $14.8 \mathrm{a}$ & $14.8 \mathrm{ab}$ & $7.6 \mathrm{c}$ \\
\hline XD10 & $1 \mathrm{qt}$ & 2.4 & $247 \mathrm{a}$ & $57 \mathrm{bc}$ & $14.9 \mathrm{a}$ & $14.8 \mathrm{ab}$ & $7.4 \mathrm{~d}$ \\
\hline
\end{tabular}

${ }^{2}$ Each treatment was replicated six times and each value is the mean from 10 fruit/replication (60 fruit). Sprays were applied on 30 Apr., 14 May, 27 May, 13 June, 24 June, 10 July, 25 July, 5 Aug., and 20 Aug. InCa ${ }^{\top \mathrm{M}}$, XD10, and XD505 are proprietary calcium products from Miller Chemical and Fertilizer Corp., Hanover, PA.

${ }^{\mathrm{y}} \mathrm{l} \mathrm{lb} / \mathrm{acre}=1.1209 \mathrm{~kg} \cdot \mathrm{ha}^{-1}, \mathrm{l} \mathrm{qt} / \mathrm{acre}=2.3385 \mathrm{~L} \cdot \mathrm{ha}^{-1}, \mathrm{l} \mathrm{lbf}=4.4482 \mathrm{~N}, 1 \mathrm{~g}=0.0353 \mathrm{oz}$.

${ }^{\mathrm{x}} \mathrm{S}$ tarch index was determined by staining the stem-side of an equatorial cross-section of the apples with iodine solution $(0.22 \% \mathrm{w} / \mathrm{v}$ iodine, $0.88 \% \mathrm{w} / \mathrm{v}$ potassium iodine $)$ and visual rating, where $1=100 \%$ staining and $8=0 \%$ staining.

${ }^{\text {w } M e a n ~ s e p a r a t i o n ~ w i t h i n ~ c o l u m n ~ b y ~ t h e ~ l e a s t ~ s i g n i f i c a n t ~ d i f f e r e n c e ~ t e s t ~}(P \leq 0.05)$.

Table 4. Bitter pit and sunburn incidence, as well as total fruit count in a 'Honeycrisp'/'Malling Merton 111 ' (MM.111) apple orchard treated with varying amounts of calcium $(\mathrm{Ca})$ chloride $\left(\mathrm{CaCl}_{2}\right)$ and other calcium products in Winchester, VA in 2011 when measured in 2012 at harvest (16 Aug.) and after $45 \mathrm{~d}$ in refrigerated storage (2 Oct.).

\begin{tabular}{|c|c|c|c|c|c|c|c|c|}
\hline Treatment $^{\mathrm{z}}$ & $\begin{array}{c}\text { Rate } \\
\text { (units/acre per } \\
\text { application) }\end{array}$ & $\begin{array}{c}\text { Total Ca } \\
(\text { lb/acre })^{\mathrm{y}}\end{array}$ & $\begin{array}{l}\text { Total fruit } \\
\text { (no./tree) }\end{array}$ & $\begin{array}{l}\text { Fruit with } \\
\text { heat or } \\
\text { sunburn } \\
\text { injury (\%) }\end{array}$ & $\begin{array}{c}\text { Bitter pit } \\
\text { rating }(0-3)^{x} \\
\text { harvest }\end{array}$ & $\begin{array}{c}\text { Fruit with } \\
\text { bitter pit } \\
(\%) \text { harvest }\end{array}$ & $\begin{array}{l}\text { Bitter pit } \\
\text { rating } \\
(0-3) 45 \mathrm{~d}\end{array}$ & $\begin{array}{c}\text { Fruit with } \\
\text { bitter pit } \\
(\%) 45 \mathrm{~d} \\
\end{array}$ \\
\hline $\mathrm{CaCl}_{2}$ (full season) & $3 \mathrm{lb}$ & 9.7 & $89 a$ & $5 \mathrm{a}$ & $0.1 \mathrm{~d}$ & $11 \mathrm{bc}$ & $0.9 \mathrm{ed}$ & $56 \mathrm{ab}$ \\
\hline $\mathrm{CaCl}_{2}$ (late season) & $3 \mathrm{lb}$ & 4.3 & $87 \mathrm{a}$ & $11 \mathrm{a}$ & $0.2 \mathrm{~cd}$ & $16 \mathrm{bc}$ & $1.4 \mathrm{bc}$ & $71 \mathrm{a}$ \\
\hline $\begin{array}{l}\mathrm{CaCl}_{2} \text { (full season) } \\
+ \text { antitranspirant }\end{array}$ & $\begin{array}{r}3 \mathrm{lb} \\
+2 \mathrm{gt}^{\mathrm{t}}\end{array}$ & 9.7 & $91 \mathrm{a}$ & $10 \mathrm{a}$ & $0.1 \mathrm{~d}$ & $8 \mathrm{c}$ & $0.6 \mathrm{e}$ & $36 \mathrm{~b}$ \\
\hline $\mathrm{XD} 10$ & $1.5 \mathrm{qt}$ & 3.7 & $94 \mathrm{a}$ & $6 a$ & $0.3 \mathrm{bcd}$ & $24 \mathrm{abc}$ & $1.5 \mathrm{abc}$ & $74 \mathrm{a}$ \\
\hline $\begin{array}{l}\text { XD10 } \\
+ \text { antitranspirant }\end{array}$ & $\begin{array}{l}1.5 \mathrm{qt} \\
+2 \mathrm{qt}\end{array}$ & 3.7 & 98 a & $6 a$ & $0.3 \mathrm{bcd}$ & $33 \mathrm{abc}$ & $1.1 \mathrm{~cd}$ & $60 \mathrm{ab}$ \\
\hline $\begin{array}{l}\text { Sysstem-Cal }{ }^{\mathrm{TM}} \\
+ \text { Vigor-Cal }^{\mathrm{TM}}\end{array}$ & $\begin{array}{r}2 q t \\
+2 q t\end{array}$ & 2.3 & $107 \mathrm{a}$ & $8 \mathrm{a}$ & $0.5 \mathrm{abc}$ & $40 \mathrm{ab}$ & $1.7 \mathrm{ab}$ & $79 \mathrm{a}$ \\
\hline Sysstem-Cal & $2 \mathrm{qt}$ & & & & & & & \\
\hline
\end{tabular}

${ }^{\mathrm{z}}$ Application dates were as follows: calcium chloride (full season) and XD10 treatments, 20 April (petal fall), 30 Apr., 10 May, 24 May, 7 June, 21 June, 5 July, 19 July, 2 Aug.; calcium chloride (late season) treatments, 21 June, 5 July, 19 July, 2 Aug.; Sysstem-Cal ${ }^{\mathrm{TM}}, 20$ Apr., 30 Apr., and 10 May, followed by Vigor-Cal ${ }^{\mathrm{TM}} 24$ May, 7 June, 21 June, 5 July, 19 July, and 2 Aug. Antitranspirant was added on 7 June, 5 July, and 2 Aug. XD10 is a proprietary calcium product from Miller Chemical and Fertilizer Corp., Hanover, $\mathrm{PA}$. Sysstem-Cal ${ }^{\mathrm{TM}}$ and Vigor-Cal ${ }^{\mathrm{TM}}$ are proprietary calcium products from Agro-K, Minneapolis, $\mathrm{MN}$.

y l lb/acre $=1.1209 \mathrm{~kg} \cdot \mathrm{ha}^{-1}, \mathrm{l} \mathrm{qt} / \mathrm{acre}=2.3385 \mathrm{~L} \cdot \mathrm{ha}^{-1}$.

${ }^{\mathrm{x}} 0=$ no bitter pit; $1=$ light amount of bitter pit, less than $15 \%$ surface area affected; $2=$ moderate amount of bitter pit, over $15 \%$ surface area affected; and $3=$ severe (heavy) amount of bitter pit, over $35 \%$ surface area affected. Each treatment was replicated six times and each value is the mean from 10 fruit/replication ( 60 fruit).

${ }^{\text {w}}$ Mean separation within column by Tukey's honestly significant difference test $(P \leq 0.05)$. 
all treatments (Table 4). We observed many 'Honeycrisp' fruit that were either sunburned or heat damaged, but there were no differences in the percent of fruit with these damages. At harvest, bitter pit incidence was high in the nonsprayed control, with an average severity of 0.7 and more than $50 \%$ of the fruit having at least some bitter pit damage. After the $45 \mathrm{~d}$ storage period, the nonsprayed controls had an average severity rating of 2.0 and nearly $90 \%$ of the fruit showed signs of bitter pit. Both the $\mathrm{CaCl}_{2}$ and XDlO treatments had lower bitter pit severity than the control, but only the $\mathrm{CaCl}_{2}$ treatments had a lower total percentage of fruit with bitter pit compared with the control. Antitranspirant only reduced bitter pit in one of the three treatments $\left(\mathrm{CaCl}_{2}\right.$ for the full season), but the effect was significant enough $(50 \%$ reduction in bitter pit) to warrant further investigation. The full and late season $\mathrm{CaCl}_{2}$ treatments performed similarly at harvest, but after $45 \mathrm{~d}$ in storage there was less incidence but not less fruit with bitter pit in the seasonlong program suggesting that $\mathrm{CaCl}_{2}$ applications may not be needed during the entire growing season.

Some maturity differences were observed among the treatments at harvest (i.e., peel color, fruit firmness, starch index, and ethylene), but the magnitude of the difference was small, and after $45 \mathrm{~d}$ in storage, the fruit was very similar for all of the measured parameters (Tables 2, 5, and 6). Unlike in 2011, the XD10 product did not delay fruit maturity as evaluated at harvest.

Experiment 3: In 2010, days with maximum temperature exceeding $90^{\circ} \mathrm{F}$ totaled 5,19 , and $14 \mathrm{~d}$ for June, July, and August, respectively. Temperatures from the period March through July were 4.5 to $6.2^{\circ} \mathrm{F}$ above normal. Total precipitation in March, April, May, June, July, and August was $4.5,3.4,5.2,1.2,2.0$, and 1.6 inches, respectively. Trees that received only $35 \mathrm{lb} /$ acre $\mathrm{CaCl}_{2}$ had lower firmness than those that received the higher amounts (13.5 lbf firmness vs. 15.1 and $14.8 \mathrm{lbf}$ for the middle and high rates, respectively). There were no differences among treatments for fruit firmness in 2012. There were no differences in percent soluble solids among the treatments in either year (Table 6).

In 2010 , trees that received $35 \mathrm{lb}$ $\mathrm{CaCl}_{2}$ had significantly more bitter pit at harvest $(25 \%$ of fruit with symptoms), compared with the middle and high treatments, which were similar (9\% and $2 \%$, respectively). Trees that received 35.0 and $50.0 \mathrm{lb} /$ acre per season $\mathrm{CaCl}_{2}$ showed no foliar phytotoxicity. However, trees receiving
$65.0 \mathrm{lb} /$ acre per season showed foliar symptoms that were typical of salt injury (necrosis of the leaf margins and tips of leaves). No phytotoxicity to fruit was observed. There were no differences among treatments in the severity (number of pits/fruit) of bitter pit at harvest in 2010 (data not shown).

In 2012, days with maximum temperature exceeding $90^{\circ} \mathrm{F}$ totaled 6, 14, and $16 \mathrm{~d}$ for June, July, and August, respectively. The 2012 growing season was atypical with twice normal monthly rainfall in May and September. Total monthly precipitation was $1.0,2.8,6.6,2.5,2.3,4.9$ and 4.4 inches, for March through September. Incidence of bitter pit at harvest was $63 \%, 60 \%$ and $18 \%$, respectively, in the low, medium and high $\mathrm{CaCl}_{2}$ treatments with no differences between the low and medium $\mathrm{CaCl}_{2}$ treatments (Table 7). The high treatment showed significantly less bitter pit than the medium and low treatments, which were similar. In 2012, fruit were examined after $\approx 90 \mathrm{~d}$ in refrigerated storage [34 ${ }^{\circ} \mathrm{F}$ (13 Nov.)]. After storage, bitter pit incidence increased to $80 \%$, $83 \%$, and $53 \%$, respectively, in the low, medium and high $\mathrm{CaCl}_{2}$ treatments with no differences between the low and medium $\mathrm{CaCl}_{2}$ treatments (Table 7). Fruit rot in storage

Table 5. Fruit weight, red peel color, fruit flesh firmness, soluble solids, starch index, and internal ethylene $\left(\mathrm{C}_{2} \mathrm{H}_{4}\right)$ concentration of 'Honeycrisp'/'Malling Merton 111' (MM.111) apples treated with varying amounts of calcium (Ca) chloride $\left(\mathrm{CaCl}_{2}\right)$ and other calcium products in Winchester, VA when measured in 2012 at harvest (16 Aug.).

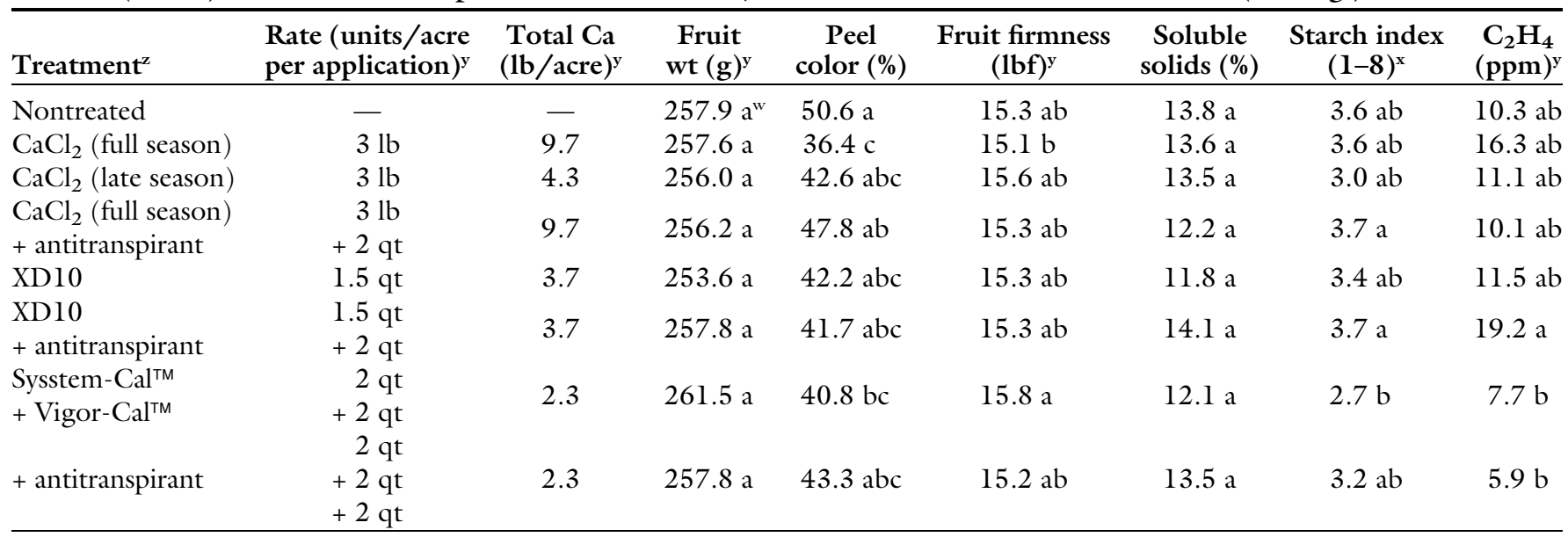

${ }^{\mathrm{z}}$ Each treatment was replicated eight times and each value is the mean from 10 fruit/replication ( 80 fruit). Application dates were as follows: calcium chloride (full season) and XD10 treatments, 20 April (petal fall), 30 Apr., 10 May, 24 May, 7 June, 21 June, 5 July, 19 July, 2 Aug.; calcium chloride (late season) treatments, 21 June, 5 July, 19 July, 2 Aug.; Sysstem-Cal ${ }^{\mathrm{TM}}, 20$ Apr., 30 Apr., and 10 May, followed by Vigor-Cal ${ }^{\mathrm{TM}} 24$ May, 7 June, 21 June, 5 July, 19 July, and 2 Aug. Antitranspirant was added on 7 June, 5 July, and 2 Aug. XD10 is a proprietary calcium product from Miller Chemical and Fertilizer Corp., Hanover, PA. Sysstem-Cal ${ }^{\mathrm{TM}}$ and Vigor-Cal ${ }^{\mathrm{TM}}$ are proprietary calcium products from Agro-K, Minneapolis, MN.

${ }^{\mathrm{y}} \mathrm{l} \mathrm{lb} / \mathrm{acre}=1.1209 \mathrm{~kg} \cdot \mathrm{ha}^{-1}, \mathrm{l} \mathrm{qt} / \mathrm{acre}=2.3385 \mathrm{~L} \cdot \mathrm{ha}^{-1}, \mathrm{llbf}=4.4482 \mathrm{~N}, \mathrm{l} \mathrm{ppm}=1 \mathrm{mg} \cdot \mathrm{L}^{-1}, \mathrm{l} \mathrm{g}=0.0353 \mathrm{oz}$.

${ }^{\mathrm{x}}$ Starch index was determined by staining the stem side of an equatorial cross-section of the apples with iodine solution ( $0.22 \% \mathrm{w} / \mathrm{v}$ iodine, $0.88 \% \mathrm{w} / \mathrm{v}$ potassium iodine) and visual rating, where $1=100 \%$ staining and $8=0 \%$ staining.

"Mean separation within column by Tukey's honestly significant difference test $(P \leq 0.05)$. 
was identified as bitter rot, caused by Colletotrichum acutatum, with $22 \%$, $17 \%$, and $5 \%$ incidence, respectively, in the low, medium and high $\mathrm{CaCl}_{2}$ treatments with no differences between the low and medium $\mathrm{CaCl}_{2}$ treatments and significantly less bitter rot in the high $\mathrm{CaCl}_{2}$ treatment. Blemish- and rot-free fruit after storage was $19 \%, 13 \%$, and $45 \%$, respectively, in the low, medium, and high $\mathrm{CaCl}_{2}$ treatments, with no differences between the low and medium $\mathrm{CaCl}_{2}$ treatments and significantly greater blemish- and rot-free fruit in the high $\mathrm{CaCl}_{2}$ treatment. Previous research has shown that $\mathrm{CaCl}_{2}$ has suppressive effects against the bitter rot pathogens (Biggs, 1999).
The mid-Atlantic U.S. region generally has moderate relative humidity and low to moderate rainfall during July and August, and these factors favor the beneficial effects on apple of exogenous Ca supplementation. Moderate air humidity is the driving force for absorption and permeability of the fruit surface (Fallahi and Eichert, 2013). If precipitation is low, Ca removal at the fruit surface is minimized, whereas, repeated spray applications are required to maintain surface $\mathrm{Ca}$ availability for absorption during seasons with regular rainfall.

Schlegel and Schonherr (2004) showed that good wetting during application was essential for penetration of $\mathrm{CaCl}_{2}$ into apple fruit. When they added a surfactant, rates of $\mathrm{Ca}$ penetration increased up to 15 -fold. They concluded that mixing of fungicides with $\mathrm{CaCl}_{2}$ would result in a very slow or even insignificant penetration of $\mathrm{CaCl}_{2}$ if the mixture has a high surface tension, likely due to formation of Ca complexes with fungicide molecules. This finding argues for the development of product formulations or surfactants that enhance penetration of solubilized $\mathrm{Ca}$. It is unlikely that producers in the midAtlantic region would separate the application of fungicides or other pesticides for summer diseases management from $\mathrm{Ca}$ supplementation, as the time and energy constraints make separate applications unfeasible;

Table 6. Fruit weight, red peel color, fruit flesh firmness, soluble solids, starch index, and internal ethylene $\left(\mathrm{C}_{2} \mathrm{H}_{4}\right)$ concentration of 'Honeycrisp'/'Malling Merton 111' (MM.111) apples treated with varying amounts of calcium (Ca) chloride $\left(\mathrm{CaCl}_{2}\right)$ and other calcium products in Winchester, VA when measured in 2012 after $45 \mathrm{~d}$ in refrigerated storage (2 Oct.).

\begin{tabular}{|c|c|c|c|c|c|c|c|c|}
\hline Treatment $^{\mathrm{z}}$ & $\begin{array}{l}\text { Rate (units/acre } \\
\text { per application) }\end{array}$ & $\begin{array}{c}\text { Total Ca } \\
(\text { lb/acre })^{y}\end{array}$ & $\begin{array}{c}\text { Fruit } \\
\text { wt }(g)^{y}\end{array}$ & $\begin{array}{c}\text { Peel } \\
\text { color }(\%)\end{array}$ & $\begin{array}{l}\text { Fruit firmness } \\
(\text { (lbf })^{y}\end{array}$ & $\begin{array}{c}\text { Soluble } \\
\text { solids (\%) }\end{array}$ & $\begin{array}{l}\text { Starch index } \\
(1-8)^{x}\end{array}$ & $\begin{array}{c}\mathrm{C}_{2} \mathrm{H}_{4} \\
(\mathrm{ppm})^{\mathrm{y}}\end{array}$ \\
\hline Nontreated & - & - & $250.5 \mathrm{a}^{\mathrm{w}}$ & $55.3 \mathrm{a}$ & $14.8 \mathrm{a}$ & $14.2 \mathrm{a}$ & $6.1 \mathrm{a}$ & $14.5 \mathrm{a}$ \\
\hline $\mathrm{CaCl}_{2}$ (full season) & $3 \mathrm{lb}$ & 9.7 & $251.3 \mathrm{a}$ & $45.6 \mathrm{~b}$ & $14.8 \mathrm{a}$ & $14.0 \mathrm{a}$ & $6.0 \mathrm{ab}$ & $15.6 \mathrm{a}$ \\
\hline $\mathrm{CaCl}_{2}$ (late season) & $3 \mathrm{lb}$ & 4.3 & $255.8 \mathrm{a}$ & $41.7 \mathrm{~b}$ & $15.0 \mathrm{a}$ & $14.1 \mathrm{a}$ & $5.3 \mathrm{~b}$ & $16.9 \mathrm{a}$ \\
\hline $\begin{array}{l}\mathrm{CaCl}_{2} \text { (full season) } \\
+ \text { antitranspirant }\end{array}$ & $\begin{array}{r}3 \mathrm{lb} \\
+2 \mathrm{qt}\end{array}$ & 9.7 & $256.7 \mathrm{a}$ & $49.7 \mathrm{ab}$ & $15.1 \mathrm{a}$ & $14.0 \mathrm{a}$ & $6.0 \mathrm{ab}$ & $7.0 \mathrm{a}$ \\
\hline $\begin{array}{l}\text { Sysstem-Cal }{ }^{T M} \\
+ \text { Vigor-Cal }^{T M}\end{array}$ & $\begin{array}{r}2 \mathrm{qt} \\
+2 \mathrm{qt} \\
2 \mathrm{qt}\end{array}$ & 2.3 & $257.8 \mathrm{a}$ & $47.6 \mathrm{ab}$ & $15.2 \mathrm{a}$ & $14.0 \mathrm{a}$ & $5.3 \mathrm{~b}$ & $12.8 \mathrm{a}$ \\
\hline+ antitranspirant & $\begin{array}{l}+2 \mathrm{qt} \\
+2 \mathrm{qt} \\
\end{array}$ & 2.3 & $251.6 \mathrm{a}$ & $45.8 \mathrm{~b}$ & $15.0 \mathrm{a}$ & $14.2 \mathrm{a}$ & $5.8 \mathrm{ab}$ & $14.8 \mathrm{a}$ \\
\hline
\end{tabular}

${ }^{2}$ Each treatment was replicated eight times and each value is the mean from 10 fruit/replication ( 80 fruit). Application dates were as follows: calcium chloride (full season) and XD1 0 treatments, 20 Apr. (petal fall), 30 Apr., 10 May, 24 May, 7 June, 21 June, 5 July, 19 July, 2 Aug.; calcium chloride (late season) treatments, 21 June, 5 July, 19 July, 2 Aug.; Sysstem-Cal' ${ }^{\mathrm{TM}}, 20$ Apr., 30 Apr., and 10 May, followed by Vigor-Cal' 24 May, 7 June, 21 June, 5 July, 19 July, and 2 Aug. Antitranspirant was added on 7 June, 5 July, and 2 Aug. XDl 0 is a proprietary calcium product from Miller Chemical and Fertilizer Corp., Hanover, PA. Sysstem-Cal ${ }^{\mathrm{TM}}$ and Vigor-Cal ${ }^{\mathrm{TM}}$ are proprietary calcium products from Agro-K, Minneapolis, MN.

${ }^{\mathrm{y}} \mathrm{l} \mathrm{lb} / \mathrm{acre}=1.1209 \mathrm{~kg} \cdot \mathrm{ha}^{-1}, \mathrm{l} \mathrm{qt} / \mathrm{acre}=2.3385 \mathrm{~L} \cdot \mathrm{ha}^{-1}, \mathrm{l} \mathrm{lbf}=4.4482 \mathrm{~N}, \mathrm{l} \mathrm{ppm}=1 \mathrm{mg} \cdot \mathrm{L}^{-1}, \mathrm{l} \mathrm{g}=0.0353 \mathrm{oz}$.

${ }^{\mathrm{x}}$ Starch index was determined by staining the stem-side of an equatorial cross-section of the apples with iodine solution $(0.22 \% \mathrm{w} / \mathrm{v}$ iodine, $0.88 \% \mathrm{w} / \mathrm{v}$ potassium iodine) and visual rating, where $1=100 \%$ staining and $8=0 \%$ staining.

${ }^{\text {w}}$ Mean separation within column by Tukey's honestly significant difference test $(P \leq 0.05)$.

Table 7. Firmness, soluble solids, and bitter pit incidence of 'Honeycrisp' apple treated with varying amounts of calcium chloride $\left(\mathrm{CaCl}_{2}\right)$ in Kearneysville, WV, during the growing season in 2010 and 2012.

\begin{tabular}{|c|c|c|c|c|c|c|c|c|}
\hline \multicolumn{2}{|c|}{ Treatment rates } & \multicolumn{3}{|c|}{ Aug. 2010 } & \multicolumn{4}{|c|}{ Aug. 2012} \\
\hline $\begin{array}{l}\mathrm{CaCl}_{2} / \mathrm{yr} \\
(\mathrm{lb} / \mathrm{acre})^{\mathrm{y}}\end{array}$ & $\begin{array}{l}\text { Total Ca } \\
(\mathrm{lb} / \mathrm{acre})\end{array}$ & $\begin{array}{c}\text { Firmness } \\
(\text { lbf })^{\mathrm{x}}\end{array}$ & $\begin{array}{c}\text { Soluble } \\
\text { solids }(\%)^{\mathrm{x}}\end{array}$ & $\begin{array}{c}\text { Fruit with } \\
\text { bitter pit (\%) }\end{array}$ & $\begin{array}{c}\text { Firmness } \\
(\text { lbf })^{x, v}\end{array}$ & $\begin{array}{c}\text { Soluble } \\
\text { solids }(\%)^{\mathrm{x}}\end{array}$ & $\begin{array}{c}\text { Fruit with } \\
\text { bitter pit }(\%)^{\mathrm{w}}\end{array}$ & $\begin{array}{l}\text { Fruit with bitter } \\
\text { pit (\%) } 90 \mathrm{~d}^{\mathrm{w}}\end{array}$ \\
\hline 50.0 & 18.1 & $15.1 \mathrm{a}$ & $14.9 \mathrm{a}$ & $9.0 \mathrm{~b}$ & $12.4 \mathrm{a}$ & $13.1 \mathrm{a}$ & $60.0 \mathrm{a}$ & $82.8 \mathrm{a}$ \\
\hline 65.0 & 23.5 & $14.8 \mathrm{a}$ & $15.3 \mathrm{a}$ & $2.0 \mathrm{~b}$ & $12.6 \mathrm{a}$ & $13.6 \mathrm{a}$ & $18.0 \mathrm{~b}$ & $53.0 \mathrm{~b}$ \\
\hline
\end{tabular}

${ }^{\mathrm{z}}$ Harvest occurred on 23 Aug. 2010 and 20 Aug. 2012.

${ }^{y}$ Calcium chloride applications were made on 10 May, 25 May, 11 June, 23 June, 7 July, 23 July, and 11 Aug., with intervening week applications made on 17 May, 4 June, 18 June, 30 June, 14 July, and 4 Aug. 2010. In 2012, application dates were 10 May, 24 May, 10 June, 22 June, 6 July, 22 July, and 10 Aug., with intervening week applications made on 16 May, 3 June, 17 June, 29 June, 13 July, and 3 Aug.; $1 \mathrm{lb} / \mathrm{acre}=1.1209 \mathrm{~kg} \cdot \mathrm{ha}^{-1}$.

${ }^{x}$ Each value is the mean from 30 fruit ( 10 fruit/replicate/treatment).

"Each value is the mean from 300 fruit (100 fruit/replicate/treatment).

v $1 \mathrm{lbf}=4.4482 \mathrm{~N}$.

"Letters denote significant differences according to analysis of variance and the Waller-Duncan $k$-ratio $t$ test $(P \leq 0.05)$. 
therefore, $\mathrm{Ca}$ will continue to be applied with fungicides until an alternative means is found to get $\mathrm{Ca}$ into the developing fruit.

Overall, our results were similar to those of Rosenberger et al. (2002), who showed that bitter pit in 'Honeycrisp' was best controlled by applying high rates of $\mathrm{CaCl}_{2}$ throughout summer. Increasing the ability of exogenously applied Ca to penetrate into the fruit tissue via enhanced product formulations may help ameliorate bitter pit while reducing energy costs associated with spray applications. However, $\mathrm{CaCl}_{2}$ sprays alone will not completely control bitter pit if other factors (i.e., crop load, fruit size, and thinning) predispose fruit to severe bitter pit. Lastly, it is likely that the amount of elemental Ca applied to the trees is of greater importance for minimizing bitter pit than the formulation. Growers will have to consider the additional costs of alternatives to $\mathrm{CaCl}_{2}$ against the potential for negative impacts from phytotoxicity and corrosion.

\section{Literature cited}

Biggs, A.R., L.M. Ingle, and W.D. Solihati. 1993. Control of alternaria rot of Nittany apple fruit with calcium chloride and fungicides. Plant Dis. 77:976-980.

Biggs, A.R. 1999. Effects of calcium salts on apple bitter rot caused by two Colletotrichum spp. Plant Dis. 83:10011005.4 .

Biggs, A.R. and S.S. Miller. 2001. Relative susceptibility of selected apple cultivars to Colletotrichum acutatum. Plant Dis. 85:657-660.
Fallahi, E., B. Fallahi, G.H. Neilsen, D. Neilsen, and F.J. Peryea. 2010. Effects of mineral nutrition on fruit quality and nutritional disorders in apples. Acta Hort. 868:49-59.

Fallahi, E. and T. Eichert. 2013. Principles and practices of foliar nutrients with an emphasis on nitrogen and calcium sprays in apple. HortTechnology 23:542547.

Neilsen, G., D. Neilsen, S. Dong, P. Toivonin, and F.J. Peryea. 2005. Application of $\mathrm{CaCl}_{2}$ sprays earlier in the season may reduce bitter pit incidence in 'Braeburn' apple. HortScience 40:1850-1853.

Mikiciuk, G., M. Malgorzata, E. Mozdzer, M. Statkiewicz, and U. Chylewska. 2015. The Effects of foliar nutrition with $\mathrm{InCa}^{\mathrm{TM}}$ fertilizer on the chemical composition of leaves and fruits of sweet cherry. J. Ecol. Eng. 16:116-119.

Pfeiffer, D.G., J.C. Bergh, R.D. Fell, C.R.R. Hooks, G.M. Peck, C.S. Walsh, K.S. Yoder, A.R. Biggs, J.B. Kotcon, J.F. Derr, R.S. Chandran, M.J. Weaver, A. Brown, and J. Parkhurst. 2014. Spray bulletin for commercial tree fruit growers. Virginia Coop. Ext. Publ. 456-419.

Rosenberger, D.A., J. Schupp, C. Watkins, K. Iungerman, S. Hoying, D. Straub, and L. Cheng. 2001. Honeycrisp: Promising profit maker or just another problem child? New York Fruit Qrtly. 9(3):9-13.

Rosenberger, D.A., J. Schupp, C. Watkins, S. Hoying, and L. Cheng. 2002. Effects of foliar applications of calcium, boron, and Flint fungicide on Incidence of bitter pit. New York Fruit Qrtly. 10(2): 15-16.
Schlegel, T.K. and J. Schonherr. 2004. Mixing calcium chloride with commercial fungicide formulations results in very slow penetration of calcium into apple fruits. J. Plant Nutr. Soil Sci. 167:357-362.

Schupp, J., R. Straub, D. Rosenberger, and C. Watkins. 2001a. Managing Honeycrisp for production and quality. Compact Fruit Tree 34:107-109.

Schupp, J.R., D.A. Rosenberger, C.B. Watkins, L. Cheng, and S.A. Hoying. $2001 \mathrm{~b}$. Understanding the bitter pit problem in Honeycrisp, p. 1-8. In: Apple handling and storage: Proc. Storage Workshop 2001, Cornell Univ., Natural Resource Agr. Eng. Serv. (NRAES) Publ. 153.

Telias, A., E. Hoover, C. Rosen, D. Bedford, and D. Cook. 2006. The effect of calcium sprays and fruit thinning on bitter pit incidence and calcium content in 'Honeycrisp' apple. J. Plant Nutr. 29:1941-1957.

Thompson-Witrick, K.A., K.M. Goodrich, A.P. Neilson, E.K. Hurley, G.M. Peck, and A.S. Stewart. 2014. Characterization of the polyphenol composition of 20 cultivars of cider, processing, and dessert apples (Malus $\times$ domestica Borkh.) grown in Virginia. J. Agr. Food Chem. 62:1018110191.

Watkins, C., J. Schupp, and D. Rosenberger. 2004. Calcium nutrition and control of calcium-related disorders. New York Fruit Qrtly. 12(2):15-21.

van Goor, B.J. 1971. The effect of frequent spraying with calcium nitrate solutions on the mineral composition and the occurrence of bitter pit of the apple Cox's Orange Pippin. J. HortScience 46:347364. 